\title{
UPAYA PENINGKATAN KEMAMPUAN PEMECAHAN MASALAH MATEMATIS SISWA KELAS VII SMP MUHAMMADIYAH 9 YOGYAKARTA MELALUI PENERAPAN PENDEKATAN PEMBELAJARAN PROBLEM POSING
}

\author{
Martalia Ardiyaningrum \\ (Dosen PGMI Sekolah Tinggi llmu Agama Alma Ata Yogyakarta)
}

\begin{abstract}
Problem-solving ability is one of the objectives to be achieved in mathematics. This capability is not only used in solving problems related to the field of mathematics, but can be used in solving the problems faced by students in the day-to-day life. One way to develop this ability in mathematics learning is learning by problem posing approach. This approach gives the opportunity for students to formulate questions that are simpler than the available problems. This research aims is to improve the ability of mathematical problem solving of students of grade VILA, Junior High School of Mubammadiyah 9 Yogyakarta through learning "problem solving". This is a classroom action research; with the subject of the research were seventh grade students of Junior High School of Mubammadiyah 9 Yogyakarta. The results of study showed that the approach can enhance the ability of posing a problem-solving mathematical, grade VII A Junior High School of Mubammadiyah 9 Yogyakarta.
\end{abstract}

Keywords : Problem posing, problem solving ability

\section{A. Pendahuluan}

Pembelajaran matematika di setiap tingkat satuan pendidikan diharapkan mampu membekali peserta didik dengan keterampilan dan kemampuan menghadapi berbagai permasalahan matematika maupun kehidupan sehari-hari. Kemampuan ini disebut sebagai daya matematis. Pelaksanaan pembelajaran matematika hendaknya dapat menumbuh kembangkan daya matematis siswa. Daya matematis ini tercantum pada tujuan pembelajaran matematika dalam kurikulum di Indonesia yang meliputi: 1) Kemampuan pemecahan masalah (problem solving), 2) Kemampuan berargumentasi (reasonning), 3) Kemampuan berkomunikasi (communication), 4) Kemampuan membuat koneksi (connection), 5) Kemampuan representasi (representation). 
Kemampuan pemecahan masalah merupakan salah satu tujuan yang ingin dicapai dalam mata pelajaran matematika. Seperti tercantum dalam Peraturan Menteri Pendidikan Nasional Nomor 22 Tahun 2006, kemampuan pemecahan masalah meliputi memahami masalah, merancang model matematika, menyelesaikan model dan menafsirkan solusi yang diperoleh. ${ }^{1}$ Kenyataan yang terjadi dilapangan tidak semua aspek dalam pemecahan masalah dapat dikuasai oleh siswa. Pada saat siswa dihadapkan pada masalah yang hanya menerapkan rumus yang telah diperoleh, masalah tersebut dengan mudah dipecahkan. Akan tetapi, saat siswa mendapatkan masalah non-rutin, siswa merasa kesulitan. Jangankan sampai pada tahap pemecahan masalah, masih terdapat siswa yang mengalami kesulitan pada tahapan memahami masalah.

Keberhasilan pembelajaran matematika salah satunya dapat dilihat dari prestasi belajar matematika. Hasil penelitian secara kolektif yang dilakukan oleh Trends in International Mathematics and Science Study (TIMSS) setiap empat tahun sekali menunjukkan bahwa prestasi belajar matematika siswa SMP di Indonesia masih dalam kategori rendah. Hasil tes TIMSS tahun 1999, 2003 dan 2007 menunjukkan skor pencapaian prestasi belajar berturut-turut 403, 411, dan 405 . Adapun ranking yang diperoleh adalah sebagai berikut: tahun 1999 mendapat ranking 34 dari 38 negara, tahun 2004 mendapat ranking 35 dari 46 negara, tahun 2007 mendapat ranking 36 dari 48 negara, dan tahun 2009 mendapat ranking 61 dari 65 negara. $^{2}$ Dengan data tersebut, dapat disimpulkan bahwa prestasi belajar matematika siswa di Indonesia masih rendah.

Kemampuan komunikasi dan pemecahan masalah matematis merupakan aspek dalam standar proses pembelajaran matematika, sedangkan keberhasilan pembelajaran matematika dapat dilihat dari prestasi belajar matematika siswa. ${ }^{3}$ Jadi, dapat kita simpulkan bahwa rendahnya prestasi belajar matematika siswa SMP di Indonesia disebabkan oleh beberapa hal, diantaranya kurangnya kesempatan yang diperoleh siswa untuk mengembangkan kemampuan pemecahan masalah matematis. hlm. 417.

${ }^{1}$ Depdiknas, Peraturan Menteri Pendidikan Nasional RI Nomor 22 Tahun 2006,

2Ina V.S.Mulis dkk, TIMSS 2007 international mathematics report: finding from IEA's trends in international mathematics and science study at the fourth and eight grades, (Chestnut Hill, MA: TIMSS \& PIRLS International Study Center,2008), hlm.48.

${ }^{3}$ NCTM, Principles and standarts for school mathematics. (Reston, VA: The National Council of Teachers of Mathematics Inc, 2000), hlm. 29. 
Berdasarkan hasil observasi terhadap pembelajaran matematika di kelas VIIA SMP Muhammadiyah 9 Yogyakarta, diperoleh fakta bahwa siswa di kelas ini memiliki kemampuan pemecahan masalah matematika dalam kategori menengah ke bawah. Hal ini diindikasikan dengan masih banyak peserta didik kelas VII A (lebih dari 50\%) yang belum mampu memahami soal-soal yang diberikan oleh guru matematika. Mereka sering melontarkan pertanyaan: "ini disuruh ngapain, Pak?", "soal ini menggunakan rumus yang mana?". Pertanyaan-pertanyaan tersebut mengindikasikan bahwa peserta didik belum mampu memahami soal yang diberikan. Saat masalah yang dihadirkan lain dari yang sebelumnya, peserta didik mengalami kebingungan, bahkan ada beberapa peserta didik yang tidak berusaha untuk menyelesaikan soal tersebut.

Berbagai pendekatan pembelajaran telah dikembangkan dengan tujuan meningkatkan kualitas pembelajaran matematika. Salah satu pendekatan yang dapat diterapkan adalah pendekatan problem posing. Pendekatan ini menekankan pada perumusan soal yang dapat mengembangkan kemampuan berpikir matematis atau menggunakan pola pikir matematis. Dengan merumuskan soal yang tersedia menjadi pertanyaan-pertanyaan yang akan mendukung siswa dalam menyelesaikan masalah yang ada, guru dapat mengetahui pemahaman siswa terhadap materi dan kesulitan yang dihadapi siswa. Pendekatan pembelajaran problem posing ini diduga cocok digunakan untuk meningkatkan kemampuan pemecahan masalah peserta didik karena pada pendekatan pembelajaran ini siswa diberi kesempatan untuk merumuskan pertanyaan-pertanyaan yang lebih sederhana mengenai soal tersebut.

Berdasarkan uraian yang telah dikemukakan di atas, maka masalah yang dikaji dalam penelitian ini adalah: bagaimana meningkatkan kemampuan pemecahan masalah matematis siswa kelas VII SMP Muhammadiyah 9 Yogyakarta melalui pendekatan pembelajaran problem posing?

\section{B. Pendekatan Pembelajaran Problem Posing secara teoritis}

Problem posing meliputi beberapa pengertian, yaitu (1) perumusan soal atau perumusan ulang soal yang telah diberikan dengan beberapa perubahan agar lebih mudah dipahami, (2) perumusan soal yang berkaitan dengan syarat-syarat pada soal yang telah diselesaikan dalam proses 
penyelesaian masalah. ${ }^{4}$ Ticha \& Hospesova juga mendefinisikan problem posing sebagai: (1) penciptaan masalah baru atau, (2) perumusan kembali masalah tertentu misalnya dengan memodifikasi atau generalisasi atas dasar pertanyaan "Bagaimana jika (tidak)", dll. Masalahnya mungkin dirumuskan sebelum atau selama proses pemecahan masalah. ${ }^{5}$ Selanjutnya pernyataan ini diperkuat oleh Silver, Downs, Leung, et al. bahwa "problem posing is of central importance in the discipline of mathematics and in the nature of mathematical thinking". Artinya bahwa problem posing adalah pusat penting dalam disiplin matematika dan dalam berpikir matematika.

Pengajuan masalah matematika terdiri dari dua aspek penting, yaitu accepting dan challenging. Accepting berkaitan dengan kemampuan siswa memahami situasi yang diberikan oleh guru atau situasi yang sulit ditentukan. Sementara challenging, berkaitan dengan sejauh mana siswa merasa tertantang dari situasi yang diberikan sehingga melahirkan kemampuan untuk mengajukan masalah matematika. ${ }^{7}$ Menurut Lavy \& Shriki dalam pembelajaran dengan problem posing, siswa dianjurkan untuk melewati tiga tingkatan pembelajaran. Pada tingkat pertama, siswa diminta untuk membuat daftar atribut masalah itu. Pada tingkat kedua mereka harus membahas pertanyaan "apa, jika, tidak", dan menyarankan alternatif untuk atribut yang tercantum. Tingkat ketiga adalah mengajukan pertanyaan baru, terinspirasi oleh alternatif. ${ }^{8}$ Menurut National Council of Teachers of Mathematics, problem posing diakui sebagai komponen penting dari pembelajaran matematika.

Dari beberapa pengertian problem posing di atas, dapat disimpulkan bahwa pendekatan problem posing merupakan pendekatan pembelajaran yang mengharuskan siswa menyusun pertanyaan sendiri dengan mengacu

${ }^{4}$ Edward A. Silver, et.al, "Posing mathematical problems: an exploratory study" dalam Journal for Research in Mathematics Education, Vol. 27, No.3,1996, hal 293-309.

${ }^{5}$ Ticha, M., \& Hospesova, A. (2010). "Problem posing and development of pedagogical content knowledge in pre-service teacher training" dalam Proceedings of CERME Vol. 6, 2002, hal.1943.

'Silver, "Posing mathematical problems ...", hal 293.

${ }^{7}$ Stephen I.Brown dan Marion I. Walter, The art of problem posing. (Mahwah, New Jersey: Lawrence Erlbaum associates Publishers, 2005), hlm.18.

8Lavy, I., \& Shriki, A, "Problem posing as a model means for developing mathematical knowledge of prospective teachers" dalam Proceeding of the $31^{\text {st }}$ Conference of the International Group for the Psychology of Mathematics Education, Seoul, Vol. 3, 2007, hal. 130. 
situasi yang dihadirkan dalam pembelajaran berdasarkan pengetahuan dan sumber belajar yang digunakan. Tujuan pembelajaran matematika dengan menggunakan pendekatan problem posing adalah untuk melatih kemampuan siswa dalam memecahkan masalah yang dihadapinya, siswa sendiri yang akan menemui jawaban atas beberapa masalah yang dihadapi, hal ini akan menjadi lebih bermakna bagi diri siswa sehingga kemampuan matematika siswa dapat meningkat melalui proses pemecahan masalah tersebut. Ini bisa dilihat dari kreativitas yang dilakukan oleh siswa sendiri dalam rangka memecahkan masalah yang dihadapinya. Penelitian tentang problem posing yang dilaksanakan Winograd menunjukkan bahwa kegiatan pembelajaran siswa menghasilkan masalah sebagai alat untuk meningkatan kemampuan pemecahan masalah dan sikap siswa terhadap matematika. ${ }^{10}$

Respon siswa yang diharapkan dari situasi atau informasi problem posing adalah respon berupa soal buatan siswa. Namun demikian, tidak tertutup kemungkinan siswa membuat yang lain, misalnya siswa hanya membuat pernyataan. Silver \& Cai mengklasifikasikan respon tersebut menurut jenisnya menjadi tiga kelompok, yaitu:

a. Pertanyaan matematika adalah pertanyaan yang memuat masalah matematika dan mempunyai kaitan dengan informasi yang diberikan. Pertanyaan matematika ini, selanjutnya diklasifikasikan ke dalam dua kategori, yaitu:

1) pertanyaan matematika yang dapat diselesaikan yaitu pertanyaan yang memuat informasi yang cukup dari situasi yang ada untuk diselesaikan, atau jika pertanyaan tersebut memiliki tujuan yang tidak sesuai dengan informasi yang ada. Selanjutnya pertanyaan matematika yang dapat diselesaikan juga dibedakan atas dua hal, yaitu pertanyaan yang memuat informasi baru dan pertanyaan yang tidak memuat informasi baru.

2) pertanyaan matematika yang tidak dapat diselesaikan.

b. Pertanyaan non matematika adalah pertanyaan yang tidak memuat masalah matematika dan tidak mempunyai kaitan dengan informasi yang diberikan.

10 Pi-Jen Lin, "Supporting teachers on designing problem-posing tasks as a tool of assessment to understand students' mathematical learning" dalam Proceedings of the 28th Conference of the International Group for the Psychology of Mathematics Education, Vol.3, 2004, hal. 258. 
c. Sedangkan pernyataan adalah kalimat yang bersifat ungkapan atau berita yang tidak memuat pertanyaan, tetapi sekedar ungkapan yang bernilai benar atau salah. ${ }^{11}$

Dalam pelaksanaannya Abu \& El Sayed mengklasifikasikan jenis problem posing menjadi 3 tipe, yaitu free problem posing (problem posing bebas), semi-structured problem posing (problem posing semi terstruktur), dan structured problem posing (problem posing terstruktur). ${ }^{12}$ Pemilihan tipe-tipe itu dapat didasarkan pada materi matematika, kemampuan siswa, hasil belajar siswa, atau tingkat berpikir siswa.

Silver \& Cai memberikan istilah problem posing yang diaplikasikan dalam tiga bentuk aktivitas kognitif matematika yang berbeda, yaitu:

a. Pengajuan pre-solusi (presolution posing) yaitu siswa membuat soal dari situasi yang diadakan kemudian siswa diminta untuk mengajukan soal dengan mengkaitkan informasi itu dengan pengetahuan yang sudah dimilikinya. Situasi dapat berupa gambar atau informasi terbuka yang dihubungkan dengan konsep tertentu. Jadi guru diharapkan mampu membuat situasi yang dapat memberikan sarana bagi siswa untuk menghasilkan masalah.

b. Pengajuan soal di dalam solusi (within solution posing) yaitu siswa mampu merumuskan ulang soal menjadi sub-sub pertanyaan baru yang urutan penyelesaiannya seperti yang telah diselesaikan sebelumnya. Jadi diharapkan siswa mampu membuat sub-sub pertanyaan baru dari sebuah pertanyaan yang ada pada soal yang bersangkutan.

c. Pengajuan soal setelah solusi (post solution posing) yaitu siswa memodifikasi tujuan atau kondisi soal yang sudah diselesaikan untuk membuat soal yang baru yang sejenis. Tujuannya untuk menghasilkan soal-soal baru yang lebih menantang. Pembuatan soal demikian merujuk pada strategi "what-if-not ...?" atau "what happen if ...". ${ }^{13}$

${ }^{11}$ Edward A.Silver dan Jinfa Cai, "An analysis of arithmetic problem posing by middle school students" dalam Journal for Research in Mathematics Education, Vol. 27, No. 5, 1996, hal.526.

${ }^{12}$ Reda Abu \& Elwan El Sayedm, "Effectiveness of problem posing strategies on perspective mathematics teachers' problem solving performance" dalam Journal of Science and Mathematics Education in S.E. Asia, Vol. XXV, No.1, 2000, 59-61.

${ }^{13}$ Silver dan Cai, An analysis of arithmetic ..., hal.523. 
Beberapa teknik yang dapat digunakan untuk membuat soal dengan strategi itu adalah sebagai berikut.

1) Mengubah informasi atau data pada soal semula.

2) Menambah informasi atau data pada soal semula.

3) Mengubah nilai data yang diberikan, tetapi tetap mempertahankan kondisi atau situasi soal semula.

4) Mengubah situasi atau kondisi soal semula, tetapi tetap mempertahankan data atau informasi yang ada pada soal semula.

Dalam menerapkan pendekatan pembelajaran problem posing, guru sebaiknya mempersiapkan strategi apa yang akan dilakukan untuk pelaksanaan pembelajaran. Xiogang Xia menyatakan

the strategies of teachers' leading role are as follows: setting up the mathematics situation, leading to problem posing, discussing and exchanging ideas, promoting cooperative study, paying attention to problem solving and mathematics application, assigning situational tasks, carrying out mathematics activities, attaching importance to intensive lecture, guiding students thinking, paying attention to reviewing and summarizing, and developing students' metacognition. $^{14}$

Artinya bahwa strategi peran guru yang terkemuka adalah sebagai berikut: menyiapkan situasi matematika yang menyebabkan problem posing, mendiskusikan dan bertukar ide, mempromosikan studi kooperatif, menaruh perhatian pada pemecahan masalah dan aplikasi matematika, menetapkan tugas situasional, melaksanakan kegiatan matematika, melampirkan hal penting untuk kuliah intensif, membimbing siswa berpikir, memperhatikan untuk meninjau dan meringkas, dan mengembangkan metakognisis siswa.

${ }^{14}$ Xiogang Xia, "Research on mathematics instruction experiment based problem posing" dalam Journal of Mathematics Education December 2008, Vol. 1, No. 1, 2008, hal 157. 
Tahapan utama dalam problem posing, yaitu:

a. Memilih titik awal.

Pemilihan titik awal dapat dengan menggunakan bahan yang konkret atau teorema.

b. Mendaftar apa yang diketahui dari masalah atau situasi yang diberikan.

c. Menggali konsep dengan pertanyaan "bagaimana-jika-tidak".

Penggalian konsep dapat dilakukan dengan menjawab pertanyaan seperti: "Bagaimana jika hal yang diketahui tidak demikian, apa yang bisa dilakukan?"

d. Mencari, mendefinisikan, dan mencatat hal yang baru berdasarkan pertanyaan "bagaimana-jika-tidak" sebelumnya.

e. Membuat pertanyaan-pertanyaan baru dan analisis pertanyaan tersebut setelah semua masalah direncanakan. ${ }^{15}$

Whithin mengemukakan langkah-langkah yang dapat dilakukan untuk menerapkan problem posing adalah sebagai berikut:

a. Melibatkan siswa dalam membahas masalah baru dengan teliti.

b. Meminta siswa mencatat tentang apa yang mereka bicarakan, mereka tulis dan mereka gambar berdasarkan temuan mereka.

c. Meminta siswa mengajukan soal atau petanyaan berdasarkan hasil pengamatan.

d. Meminta siswa untuk memilih salah satu soal atau pertanyaan yang mereka buat untuk diprediksikan solusinya.

e. Memberikan kesempatan kepada siswa untuk membandingkan atau mendiskusikan temuan mereka dengan siswa yang lain. ${ }^{16}$

Dari pendapat-pendapat tersebut dapat disimpulkan, langkahlangkah penerapan pendekatan problem posing dalam pembelajaran matematika adalah sebagai berikut:

a. Guru menyajikan informasi atau situasi kepada siswa dengan menggunakan gambar, benda manipulatif, permainan, teorema atau konsep, alat peraga, soal, atau selesaian dari suatu soal.

b. Siswa mencatat hal-hal yang telah diketahui dari situasi atau informasi yang telah diberikan.

${ }^{15}$ Brown \& Walter, The art of ..., hlm.19-52.

${ }^{16}$ Lebih lanjut lihat: http://www.ceefcares.org/flyers/ promotingproblempo singperimeter.pdf 
c. Siswa membuat pertanyaan atau soal dengan menggali konsep dari hal-hal yang telah diketahui.

d. Siswa menganalisis pertanyaan atau soal yang telah dibuat dan memprediksi solusi dari soal tersebut .

Siswa mendiskusikan hasil pekerjaannya dengan siswa yang lain.

\section{Pengertian Kemampuan Pemecahan Masalah}

Dalam pembelajaran matematika, kemampuan pemecahan masalah merupakan salah satu tujuan yang harus dicapai. Oleh karenanya guru matematika harus berusaha agar siswa memiliki kemampuan tersebut. Pemecahan masalah merupakan suatu usaha untuk mencapai tujuan yang diinginkan dan tidak secara otomatis diketahui cara yang tepat untuk mencapai tujuan tersebut. ${ }^{17}$ Nitko \& Brookhart menambahkan bahwa mencapai suatu tujuan atau menyelesaikan suatu tugas tanpa melakukan pemikiran tidaklah dikatakan sebagai pemecahan masalah melainkan nobrainers. Haylock juga menyatakan hal yang senada yaitu "problem solving is when the individual use think mathematical knowledge and reasoning to close the gap between thye givens and the goal". ${ }^{18}$ Untuk dapat memecahkan suatu pernyataan yang dikategorikan masalah diperlukan keterampilan yang lebih dikenal sebagai kemampuan pemecahan masalah. Kemampuan pemecahan masalah merupakan keterampilan kognitif terpenting dalam belajar matematika.

Pemecahan masalah merupakan bagian dari kurikulum matematika yang sangat penting karena dalam proses pembelajaran maupun saat penyelesaian suatu masalah, siswa dapat memperoleh pengalaman menggunakan pengetahuannya serta ketrampilan yang sudah dimiliki untuk diterapkan pada pemecahan masalah yang tidak rutin. ${ }^{19}$ Selain itu, Kementerian Pendidikan Singapura mengungkapkan bahwa

"mathematical problem solving is central to mathematics learning. It involves the acquisition and application of mathematics concepts and skills in a wide

${ }^{17}$ Anthony J. Nitko \& Susan M. Brookhart, Educational assessment of students. (Upper Saddle River, Pearson Education Inc, 2007).

${ }^{18}$ Derek Haylock \& Fiona Thangata, Key concepts in teaching primary mathematics (London, SAGE Publications, 2007), hal. 145-146.

${ }^{19}$ Erman Suherman, dkk, Strategi pembelajaran matematika kontemporer (Rev.ed.), (Bandung, JICA, 2003), hal.89. 
range of situation, including non-routine, open-ended, and real-world problems". ${ }^{20}$

Hal ini menunjukkan bahwa pemecahan masalah memiliki peranan yang sangat penting dalam pembelajaran matematika. Dalam pemecahan masalah harus menerapkan konsep dan keterampilan yang luas, meliputi masalah tidak rutin, open-ended, dan masalah yang sesuai dengan dunia nyata. NCTM juga menyatakan bahwa "through problem solving, student can experience the power and utility of mathematics" ${ }^{21}$ Maksunya, melalui pemecahan masalah siswa dapat mengetahui kekuatan dan kegunaan matematika.

Menurut Krulik \& Rudnick mengemukakan "problem solving as the means by which an individual uses previously acquired knowledge, skills, and understanding to satisfy the demands of an unfamiliar situation".22 Pendapat tersebut berarti bahwa pemecahan masalah adalah sarana yang memungkinkan seorang individu menggunakan pengetahuan yang diperoleh sebelumnya, keterampilan, dan pemahaman untuk memenuhi tuntutan keadaan yang tidak biasa. Bahkan dalam pembelajaran matematika pemecahan masalah mempunyai interpretasi berbeda, misalnya menyelesaikan soal cerita, soal yang tidak rutin, dan mengaplikasikan matematika dalam kehidupan sehari-hari.

Kemampuan pemecahan masalah diperlukan untuk menyelesaikan masalah tidak rutin. ${ }^{23}$ Adapun langkah-langkah dalam pemecahan masalah adalah sebagai berikut.

a. Memahami masalah

Langkah pertama ini adalah sangat penting dalam pemecahan masalah, karena tanpa pemahaman yang benar terhadap masalah basar kemungkinan sisaw akan salah atau tidak dapat memecahkan masalah. Beberapa hal yang harus diketahui siswa yang dapat menunjukkan bahwa ia sudah memahami masalah yang diberikan, yaitu siswa mengetahui: (1) apa yang tidak diketahui dan apa yang diketahui, (2)

\footnotetext{
${ }^{20}$ Lebih lanjut lihat: http://www.hmheducation.com/singaporemath/ pdf/MIFProbSolving. pdf.

${ }^{21}$ NCTM, Principles and standards ..., hlm. 256.

${ }^{22}$ Jamin Carson, "A problem with problem solving: teaching thinking without teaching knowledge" dalam Journal of The Mathematics Educator 2007, Vol. 17, No. 2, 2007, hlm.7.

${ }^{23}$ George Polya, How to Solve It, a new aspect of Mathematical Method. (Princeton, New Jersey: Princenton, 1985), hal 5-15.
} 
hal-hal apa yang sudah diketahui sebagai data, dan (3) apakah data-data tersebut cukup untuk menemukan hal-hal yang tidak diketahui, atau ada data yang kurang atau bertolak belakang?

Pada langkah ini siswa juga diharapkan dapat member gambaran tentang masalah dan menuliskan masalah dengan notasi-notasi dan symbol-simbol yang diperlukan.

b. Merencanakan pemecahan

Pada langkah ini siswa diharuskan menemukan koneksi antara data yang diketahui dan hal yang tidak diketahui. Diharapkan siswa akan berusaha mengingat masalah-masalah yang pernah dikenalnya yang berhubungan dengan masalah yang dihadapinya, dan menjadikannya alat untuk penyelesaian. Selain itu siswa akan mencari teorema-teorema yang dianggapnya berguna untuk menyelesaikan masalah. Selanjutnya siswa merencanakan penyelesaian masalah menggunakan data-data yang ada dan teorema-teorema yang diingatnya.

c. Melaksanakan rencana

Pada langkah ini siswa melaksanakan langkah-langkah penyelesaian seperti yang sudah direncanakan sebelumnya. Dan meneliti apakah langkah-langkah yang digunakan sudah tepat.

d. Memeriksa kembali

Pada langkah ini siswa dituntut untuk memeriksa kembali hasil pekerjaannya dari awal sampai dengan akhir kegiatan pemecahan masalah.

Berdasarkan definisi-definisi di atas, maka dapat disimpulkan pengertian kemampuan pemecahan masalah dalam matematika yaitu suatu kemampuan yang ditunjukkan siswa dalam menyelesaikan masalah matematika yang tidak rutin dengan menggunakan langkah-langkah penyelesaian untuk mencapai hasil yang diharapkan.

\section{Metode Penelitian}

Penelitian ini merupakan penelitian tindakan kelas yang terdiri dari dua siklus. Pada siklus pertama mencakup dua kali pertemuan dan siklus kedua juga terdiri dari dua kali pertemuan. Setiap siklus mencakup kegiatan perencanaan, pelaksanaan tindakan, pengamatan, dan refleksi. 


\section{a. Subjek Penelitian}

Subjek pada penelitian tindakan kelas ini adalah siswa kelas VII A SMP Muhammadiyah 9 Yogyakarta dengan jumlah 21 siswa yang terdiri dari 13 siswa laki-laki dan 8 siswa perempuan.

\section{b. Instrumen Penelitian}

Untuk memperoleh data dalam penelitian ini digunakan instrument berupa lembar observasi dan soal tes. Lembar observasi digunakan untuk mencatat hasil pengamatan selama proses pembelajaran berlangsung untuk mendapatkan data yang akurat dalam pengamatan. Sedangkan soal tes digunakan untuk mengukur kemampuan pemecahan masalah matematis siswa. Tes kemampuan pemecahan masalah tersebut hanya mengamati tiga aspek dalam kemampuan pemecahan masalah yaitu memahami masalah, merencanakan penyelesaian, dan melaksanakan perencanaan.

\section{c. Teknik Analisis Data}

Analisis data dilakukan sejak data diperoleh dari hasil pelaksanaan kegiatan ataupun observasi. Teknik analisis data yang digunakan dalam penelitian ini adalah sebagai berikut:

1. Peningkatan kemampuan pemecahan masalah matematis

Untuk mengetahui peningkatan kemampuan pemecahan masalah siswa adalah dengan melaksanakan tes. Soal tes berbentuk uraian. Pemberian skor tes didasarkan pada rubrik pemecahan masalah. Berdasar hasil tes siswa, diperoleh skor total untuk setiap siswa dan skor total untuk masing-masing aspek dalam kemampuan pemecahan masalah (memahami masalah, merencanakan penyelesaian, dan melaksanakan perencanaan). Setelah diperoleh skor setiap siswa kemudian peneliti menentukan persentase siswa yang memenuhi criteria keberhasilan kemampuan pemecahan masalah yang telah ditentukan. Kriteria keberhasilan dalam penelitian ini adalah 14 siswa (67\%) mencapai skor kemampuan pemecahan masalah 70 .

2. Pelaksanaan pembelajaran

Untuk mengetahui pelaksanaan pembelajaran digunakan pedoman observasi dan catatan lapangan. Pernyataan dalam pedoman observasi mempunyai dua laternatif jawaban, yaitu "ya" atau "tidak". Pengisian lembar observasi yaitu dengan memberikan tanda " $\sqrt{ }$ " pada kolom yang telah disediakan. 


\section{E. Hasil dan Pembahasan}

Dalam penelitian ini, kemampuan pemecahan masalah matematis siswa dikatakan meningkat jika $66 \%$ siswa mencapai skor 70 . Hasil evaluasi siklus I dan II dari kemampuan pemecahan masalah matematis siswa kelas VII salah satu SMP Swasta di Yogyakarta yang mencapai skor $\geq 70$ dapat disajikan dalam persentase seperti pada tabel berikut ini:

Tabel 1.

Hasil kemampuan pemecahan masalah matematis siswa kelas VII

\begin{tabular}{|l|l|l|l|l|l|}
\hline \multirow{2}{*}{ Aspek } & \multirow{2}{*}{ Target } & \multicolumn{2}{c|}{ Siklus I } & \multicolumn{2}{c|}{ Siklus II } \\
\cline { 3 - 6 } & & Pretest & \multicolumn{1}{c|}{ Posttest } & Pretest & Posttest \\
\hline $\begin{array}{l}\text { Kemampuan } \\
\text { Pemecahan }\end{array}$ & $\geq 14$ siswa & 1 siswa & $7 \quad$ siswa & 3 siswa & 15 siswa \\
$\begin{array}{l}\text { Masalah } \\
\text { Matematis }\end{array}$ & $(66 \%)$ & $(4,76 \%)$ & $(33,33 \%)$ & $(14,23 \%)$ & $(71,43 \%)$ \\
\hline
\end{tabular}

Berdasarkan hasil yang tersaji pada tabel di atas, peningkatan kemampuan pemecahan masalah matematis siswa tercapai pada siklus ke II. Hal ini ditunjukkan dengan 15 siswa telah mencapai skor kemampuan pemecahan masalah $\geq 70$ dengan persentase $71,43 \%$. Hasil tiap siklus dapat di uraikan sebagai berikut:

1. Hasil ketuntasan tes kemampuan pemecahan masalah yang diperoleh pada siklus I secara ringkas adalah sebagai berikut:
a) Jumlah siswa yang tuntas
: 7 orang
b) Jumlah siswa yang tidak tuntas
: 14 orang
c) Porsentase ketuntasan
: $33,33 \%$

2. Hasil ketuntasan tes kemampuan pemecahan masalah yang diperoleh pada siklus II secara ringkas adalah sebagai berikut:
a) Jumlah siswa yang tuntas
$: 15$ orang
b) Jumlah siswa yang tidak tuntas
: 6 orang
c) Porsentase ketuntasan
$: 71,43 \%$

Hasil di atas merupakan hasil penelitian secara keseluruhan, sedangkan secara terinci dapat dilihat peningkatan tiap aspek kemampuan pemecahan masalah matematis siswa. Berdasarkan rubrik yang digunakan diperoleh nilai aspek-aspek kemampuan pemecahan masalah matematis siswa sebagai berikut: 
Tabel 2.

Skor Kemampuan Pemecahan Masalah Tiap Indikator

\begin{tabular}{|l|c|c|c|c|}
\hline \multirow{2}{*}{ Indikator } & \multicolumn{2}{|c|}{ Siklus I } & \multicolumn{2}{c|}{ Siklus II } \\
\cline { 2 - 5 } & Pretest & Posttest & Pretest & Posttest \\
\hline Memahami Masalah & 155 & 224 & 251 & 298 \\
\hline Merencanaka penyelesaian & 99 & 177 & 167 & 238 \\
\hline Memperoleh penyelesaian & 48 & 134 & 101 & 177 \\
\hline
\end{tabular}

Tabel di atas menunjukkan skor kemampuan pemecahan masalah tiap indicator dari keseluruhan siswa. Dari table tersebut diperoleh informasi bahwa kemampuan pemahaman masalah siklus I menunjukkan peningkatan nilai posttest dari pretest sebesar 69, sedangkan pada indicator merencanakan penyelesaian menunjukkan peningkatan 78 dan pada indikator memperoleh penyelesaian meningkat sebesar 86 . Sedangkan pada siklus II menunjukkan peningkatan kemampuan pemahaman masalah sebesar 47, pada indikator merencanakan penyelesaian sebesar 71 , dan indikator memperoleh penyelesaian meningkat sebesar 76.

Berdasarkan hasil penelitian yang telah diperoleh pada pretest siklus I, hanya terdapat 1 siswa yang mampu mencapai skor kemampuan pemecahan masalah $\geq 70$. Hal ini berarti sebagian besar siswa kelas VII A SMP Muhammadiyah 9 Yogyakarta memiliki kemampuan pemecahan yang masih rendah. Sedangkan setelah diberikan tindakan berupa pendekatan pembelajaran problem posing, diperoleh hasil yaitu 7 siswa (33,33\%) memperoleh skor kemampuan pemecahan masalah matematis $\geq 70$. Keadaan ini menunjukkan bahwa pendekatan problem posing yang memberikan kesempatan kepada siswa untuk menyusun masalah matematis yang ada dalam pikiran mereka dan menjawab pertanyaan yang disusun oleh teman memberikan dampak yang baik untuk menyelesaikan masalah matematis. Sehingga diperoleh siswa yang memperoleh skor $\geq 70$ terdapat 7 siswa.

Banyak siswa yang memperoleh skor kemampuan pemecahan masalah $\geq 70$ belum mencapai 14 orang. Salah satu penyebabnya adalah pada saat awal diberikan pendekatan problem posing, siswa masih merasa kesulitan dalam menyusun masalah matematis yang berkaitan dengan materi aljabar. Sehingga pada siklus ini siswa perlu menyesuaikan diri dengan penyusunan soal/masalah matematis. Selain itu, berdasarkan hasil observasi yang 
dilakukan oleh observer maka diperlukan refleksi pada siklus I. Refleksi yang diberikan oleh observer adalah sebagai berikut:

a. Mengontrol dan mengawasi siswa dalam mengerjakan LKS

b. Guru menunjuk langsung perwakilan siswa yang mewakili masing-masing kelompok untuk mempresentasikan hasil diskusi. Karena pada siklus I siswa enggan untuk mempresentasikan hasil diskusi kelompoknya.

c. Berusaha mengarahkan siswa untuk mengerjakan tugas rumah yaitu dengan mengumumkan bahwa tugas tersebut dikumpulkan pada pertemuan berikutnya, agar mempelajari kembali materi yang telah dipelajari disekolah.

d. Ketika diskusi kelompok berlangsung, hanya sebagian siswa yang menyelesaikan soal-soal dalam LKS, sedangkan yang lain tidak terlibat secara aktif dalam kelompok bahkan ada yang menggambar dan berbincang dengan teman lainnya. Sehingga pembagian kelompok pada pertemuan berikutnya perlu diperhatikan distribusi siswanya.

e. Ketika kelompok ahli diminta untuk menjelaskan materi pembelajaran yang dipelajari kepada kelompok asalnya, banyak siswa yang masih mengalami kesulitan tetapi tidak mau bertanya. Dalam hal ini guru perlu memancing pertanyaan-pertanyaan dari siswa tentang bagian yang belum mereka pahami.

Setelah diadakan refleksi pada siklus I, maka penelitian ini dilanjutkan pada siklus II. Skor kemampuan pemecahan masalah matematis pada awal pertemuan siklus II (pretest) menunjukkan bahwa 3 siswa $(14,23 \%)$ telah mencapai skor $\geq 70$. Sedangkan setelah diberikan tindakan berupa pendekatan pembelajaran problem posing, diperoleh hasil yaitu 15 siswa $(71,43 \%)$ memperoleh skor kemampuan pemecahan masalah matematis $\geq 70$. Hal ini menunjukkan bahwa indikator keberhasilan penelitian ini telah tercapai yaitu 14 siswa mencapai skor kemampuan pemecahan masalah matematis $\geq 70$. Ketercapaian ini tidak lepas dari sudah terbiasanya siswa dalam menyusun soal/masalah matematis yang terkait dengan materi yang ada. Dengan kemampuan siswa menyusun masalah dengan baik maka akan meningkatkan pemahaman materi yang ada. Sedangkan kemampuan pemecahan masalah siswa dapat dilatih dengan menyelesaikan soal/masalah yang disusun oleh teman-temannya.

Pada tabel skor kemampuan pemecahan masalah tiap indikator menunjukkan bahwa masing-masing indikator kemampuan pemecahan masalah matematis meningkat setelah diberikan tindakan berupa pendekatan problem posing. Hal ini disebabkan karena pada pemberian tindakan tersebut siswa memperoleh kesempatan untuk menyusun masalah dengan memahami 
situasi yang dihadirkan dalam LKS. Setelah itu menyelesaikan soal/masalah yang disusun oleh teman. Dalam menyelesaikan masalah yang diberikan oleh temannya, siswa perlu memahami masalah tersebut, setelah itu merencanakan dan menyelesaikan dengan rencana yang telah disusun. Hal ini menunjukkan bahwa pendekatan problem posing akan memberikan kesempatan kepada siswa untuk mengembangkan kemampuan pemecahan masalah matematis.

\section{F. Kesimpulan}

Berdasarkan proses tindakan dan hasil evaluasi dari penelitian ini dapat disimpulkan bahwa penerapan pendekatan pembelajaran problem posing dapat meningkatkan kemampuan pemecahan masalah matematis siswa kelas VII A SMP Muhammadiyah 9 Yogyakarta pada kompetensi dasar melakukan operasi pada bentuk aljabar. Hal-hal yang perlu diperhatikan dalam pelaksanaan pendekatan pembelajaran problem posing adalah sebagai berikut:

1. Guru mengontrol dan mengawasi siswa dalam mengerjakan LKS

2. Guru berusaha mengarahkan siswa untuk mengerjakan tugas rumah yaitu dengan mengumumkan bahwa tugas tersebut dikumpulkan pada pertemuan berikutnya, agar siswa mempelajari kembali materi yang telah dipelajari disekolah.

3. Guru perlu memperhatikan distribusi siswa dalam pembagian kelompok.

4. Guru perlu memancing pertanyaan-pertanyaan dari siswa tentang bagian yang belum mereka pahami dalam diskusi kelas dengan bertanya/memberikan pernyataan. 


\section{DAFTAR PUSTAKA}

Abu, R., \& El Sayed, E. (2000). Effectiveness of problem posing strategies on perspective mathematics teachers' problem solving performance. Journal of Science and Mathematics Education in S.E. Asia, Vol. XXV, No.1, 56-69.

Brown, S.I., dan Walter, M.I. (2005). The art of problem posing. Mahwah, New Jersey: Lawrence Erlbaum associates Publishers.

Carson, J. (2007). A problem with problem solving: teaching thinking without teaching knowledge. Journal of The Mathematics Educator 2007, Vol. 17, No. 2, 7-15.

Clark, A. (2009). Problem solving in Singapore Math. Diambil pada tanggal 18 Januari 2012, dari http://www.hmheducation.com/singaporemath/ pdf/MIFProbSolving. pdf.

Depdiknas. (2007). Peraturan Menteri Pendidikan Nasional RI Nomor 41 Tabun 2007, tentang Standar Proses untuk Satuan Pendidikan Dasar dan Menengah.

Lavy, I., \& Shriki, A. (2007). Problem posing as a model means for developing mathematical knowledge of prospective teachers. Proceeding of the $31^{\text {st }}$ Conference of the International Group for the Psychology of Mathematics Education, Seoul, 3, 129-136.

Mullis, I. V. S., Martin, M. O., \& Foy, P. (2008). TIMSS 2007 international mathematics report: finding from IE $A$ 's trends in international mathematics and science study at the fourth and eight grades. Chestnut Hill, MA: TIMSS \& PIRLS International Study Center.

NCTM. (2000). Principles and standarts for school mathematics. Reston, VA: The National Council of Teachers of Mathematics, Inc.

Nitko, A. J., \& Brookhart, S.M. (2007). Educational assessment of students. Upper Saddle River, New Jersey: Pearson Education, Inc.

Pi-Jen Lin. (2004). Supporting teachers on designing problem-posing tasks as a tool of assessment to understand students' mathematical learning. Proceedings of the 28th Conference of the International Group for the Psychology of Mathematics Education, 3, 257-264.

Polya, G. (1985). How to Solve It, a new aspect of Mathematical Method. Princeton, New Jersey: Princenton.

Silver, E. A., \& Cai, J. (1996). An analysis of arithmetic problem posing by middle school students. Journal for Research in Mathematics Education, Vol. 27, No. 5, 521-539. 
Silver, E. A., Downs, J. M., Leung, S. S., et al. (1996). Posing mathematical problems: an exploratory study. Journal for Research in Mathematics Education, 27(3), 293-309.

Ticha, M., \& Hospesova, A. (2010). Problem posing and development of pedagogical content knowledge in pre-service teacher training. Proceedings of CERME 6, France, 1941-1950.

Whitin, P. (2004). Promoting problem posing explorations. In Teaching Children Mathematics, NCTM [online]. Diambil pada tanggal 25 Desember 2011, dari http:/ / www.ceefcares.org/flyers/promotingproblemposingperimeter.p df.

Xiogang Xia. (2008). Research on mathematics instruction experiment based problem posing. Journal of Mathematics Education December 2008, Vol. 1, No. 1, pp.153-163. Guizhou Normal University, China. 